\title{
Business Education Students' Perceptions of the Relevance of Socio-Cultural Factors in Entrepreneurial Venture in Edo State, Nigeria
}

\author{
Imeokparia, P.O. (Mrs.) \\ Department Of Vocational And Technical Education, Faculty Of Education, Ambrose Alli University, Ekpoma, \\ Edo State, Nigeria
}

\begin{abstract}
The researcher empirically investigated the perceptions of Business Education Students on the relevance of Entrepreneurship Education at the Colleges of Education in Edo State. The main purpose of this research was to find out the perceptions of Business Education students on the relevance of Entrepreneurship Education. In order to empirically investigate this study, the researcher raised four (4) research questions. Related literatures were reviewed and the Entrepreneurial Event Model (EEM) developed by Shapero and Sokol in 1982 was used in explaining the various socio-cultural factors relevant in entrepreneurial venture. The survey design was used in the study. Eight hundred and ten (810) Business Education students from both Colleges of Education in the state formed the population of the study out of which a sample size of one hundred and sixty two (162) students was selected using the proportionate stratified random sampling technique. The instrument used was the questionnaire titled: Business Education Students' Perceptions of Socio-Cultural factors in Entrepreneurship Education Questionnaire (BESPSEEQ) and it was divided into two sections - $A$ and $B$. Section A consist of the demographic information of the respondents while section $B$ consist of twenty five (20) opinion statements structured in 4-point rating scale. The instrument was validated by three (3) experts and the test re-test method of reliability was used in obtaining reliability co-efficient of 0.78 . The instrument was administered to the respondents with the help of research assistants and the data collated was subjected to statistical analyses. The descriptive and inferential statistical tools were used in analyzing the data. The findings revealed that financial factor, family factor and cultural factor have relevance in entrepreneurship. It also revealed that skills and Entrepreneurship Education has impact on economic development. One of the recommendations advanced by the researcher was that government should provide accessible and affordable loan facilities for graduates of the programme.
\end{abstract}

\section{Introduction}

The need to accelerating and promoting the growth of entrepreneurial venture in the country has remained a focal point in the nation's debate owing to the level of unemployment, insecurity, human capital flight, brain drains and underutilization of the nation's vast human and material resources. The need to promoting entrepreneurial venture is not unconnected with the drive behind the introduction of Entrepreneurship education across the tiers of the nation's tertiary institutions (Ediagbonya, 2013). The teaching and learning of Entrepreneurship Education in tertiary institutions is of paramount interest to all stakeholders. The National Policy on Education describes Education as an instrument 'par excellence' for effecting national development (FRN, 2004). It is conceived that Education is capable of bringing about the desired socio-economic and political changes in the country. The recent clamour for the inclusion of Entrepreneurship education in tertiary educational institutions in Nigeria is an indication of its importance to employment creation and thereby reducing the social vices in the county.

In the western world, the need to recognizing Entrepreneurship education started to gain prominence immediately after the Second World War. After the World War 11 that lasted for a period of six (6) years (1939 - 1945), there was evidence of collapse of most of the structures of the economy thereby making it impossible for the Government to fully absorb all the graduates of the educational system. Though the situation during those periods were not the same with what was obtainable in Third World countries like Nigeria. The discovery of crude oil at Oloibiri in the 1950s subsequently led to oil boom in the country and there were enough funds in the Government treasury to fully absorb all the graduates of the educational system at various levels. The collapse of the oil boom thereby leading to economic recession in the country with its accompanying problems unemployment, poverty and social vices redirected the focus of Nigerians. The increasing level of unemployment in the country was what informed the introduction of Entrepreneurship education in 2006 by the Federal Government to remedy the problems of unemployment, poverty and unrest in the country (Ediagbonya, 2013; Imeokparia \& Ediagbonya, 2013). 
The Government in a bid to transforming the nation and promoting the growth of entrepreneurial venture, made Entrepreneurship education programme compulsory for students of higher education institutions irrespective of area of specialization. It has been adopted as a compulsory general studies course for students. The programme has equally been made a core subject in the secondary school curricula and it is called 'trade subject'. The overall objective of Entrepreneurship education is to continuously foster entrepreneurship culture and spirit amongst students and faculty with a view to educating them as well as supporting graduates of the system towards establishing and also maintaining sustainable entrepreneurial ventures (Urbano, Aponte \& Toledano, 2008).

The term perception refers to an idea, a belief or an image you have as a result of how you see or understand something (Hornby, 2001). The relevance of Entrepreneurship education has been perceived by stakeholders in different dimensions. This kind of educational programme is primarily concerned with the formation of entrepreneurial ventures and there are several variables/factors that tend to influence the formation of entrepreneurial ventures. Some of the factors that are relevant in the formation of entrepreneurial ventures as perceived by scholars includes: financial support, cultural factors, entrepreneurial skills and family support. Financial support in this context refers to various kinds of funding or financial assistance available and accessible to would-be business owner. The establishment and management of any entrepreneurial venture rely greatly on the finances available and accessible to the entrepreneurs. The prevailing culture in terms of the value system, pattern of living, belief and societal stability in a place has relevance in the formation of entrepreneurial ventures (Shapero \& Sokol, 1982). The culture of the people in this nation varies from one region to another and the belief system equally varies; and this has relevance in starting and managing an entrepreneurial venture. Shapero and Sokol (1982) stressed that the kind of support received from family members and relatives have relevance in starting up an entrepreneurial venture. All the aforementioned socio-cultural variables seem to have relevance in entrepreneurial venture which will ultimately transform the economy towards attaining economic development.

\section{Statement of the Problem}

The need to increasing the level of entrepreneurial venture in the country has occupied a centre piece in recent debates owing to the inability of the government and organized private sector to employ the graduates that are being churn out of the nation's tertiary institutions. There have been several policies and policy statements aimed at addressing the current level of unemployment in the country. The country's unemployment level is becoming embarrassing to all stakeholders. For instance, the unemployment rate as at 2006 was 5.3 percent but as at 2011, it has risen to 23.9 percent. Many graduates seem to be roaming the streets in search for white collar jobs. The rate of poverty, corruption and so many other social vices has become worrisome to the government and to every well meaning citizen. Entrepreneurship education was introduced into Nigeria's tertiary education sub-sector in 2006 as intervention programme to remedy the unemployment challenge; and redirect the attention of our youths/graduates towards job creation by instilling in them relevant entrepreneurial skills that will positively grow and develop the economy. The goals and objectives of the programme seem laudable and for these goals and objectives to be achieved, some machinery has to be put in place. The relevance of this programme in the curriculum of all tertiary institutions in Nigeria is geared at creating an entrepreneurial culture and entrepreneurial spirits in the students. Since the introduction of this programme, the rate of poverty, corruption and so many other social vices seem not to have decreased. It seems there are other factors other than entrepreneurial skills that are capable of strengthening and promoting the growth of entrepreneurial venture. It is on the basis of this premise that the researcher intends to empirically investigate business education students' perceptions of the relevance of socio-cultural factors in entrepreneurial venture.

\section{Purpose of the Study}

The main purpose of this research work was to find out business education students' perceptions of the relevance of socio-cultural factors in entrepreneurial venture. The specific purposes included the following:

i. the extent to which financial support has relevance in starting up an entrepreneurial venture;

ii. the extent to which culture has relevance in starting up an entrepreneurial venture;

iii. the extent to which family support has relevance in starting up an entrepreneurial venture;

iv. the extent to which Entrepreneurship education has relevance on economic development;

\section{Research Questions}

This study was guided by the following research questions:

i. to what extent does financial support has relevance in starting up an entrepreneurial venture?

ii. to what extent does culture has relevance in starting up an entrepreneurial venture?

iii. to what extent does family support has relevance in starting up an entrepreneurial venture?

iv. to what extent does Entrepreneurship Education has relevance on economic development? 


\section{Significance of the Study}

The findings of this empirical investigation will indeed be of importance to all the stakeholders in the field of education and entrepreneurship/business education in particular. Some of the stakeholders to benefit from the results of this empirical investigation includes: Government, Researchers, Entrepreneurship Educators/teachers, students, employers of labour, and business consultants.

\section{Methodology}

This study adopted survey design since it was basically an enquiry into business education students' perceptions of the relevance of socio-cultural factors in entrepreneurial venture in Edo State. This is in agreement with Nworgu (1991) as cited in Omoroguiwa (2006) that a research survey is one in which a group of people or items is studied by collection and analyzing data from only a few people or items considered to be representative of the entire population. The proportionate stratified random sampling technique was used in selecting one hundred and sixty two (162) out of a population of eight hundred and ten (810) Business education students from two colleges of education in the state and the colleges are: College of Education, Ekiadolor and College of Education, Igueben. The structured questionnaire designed in 4-point rating and titled: Business Education Students' Perceptions of Entrepreneurship Education Questionnaire (BESPEEQ) was used in eliciting responses from the students and the instrument had two sections and the first part was on demographic information while the second part was on opinion statements relating to the research questions. The instrument was validated by three experts from University of Benin, Benin City and their inputs were incorporated into the final draft of the instrument. The test re-test method of reliability was used in ascertaining the reliability of the instrument and a coefficient of 0.78 was obtained. Immediately after the administration and collation of the instrument, the data was analyzed using descriptive statistics - mean and standard deviation. Any mean value of 2.50 and above was considered as accepted while below 2.50 was considered as rejected.

\section{Results And Discussion Of Findings}

\section{Answering of Research Questions}

This section is concerned with the analysis and presentation of the data regarding the four questions. The descriptive statistics used here are presented in tables and they include mean and standard deviation; and the mean value of 2.50 was used in taking decision.

Research Question One: To what extent does financial support has relevance in starting up an entrepreneurial venture?

Table 1: Examination of the Relevance of Financial Support in Entrepreneurship

\begin{tabular}{|l|l|l|l|l|l|}
\hline S/N & Financial Support & $\mathbf{N}$ & Mean & SD & Decision \\
\hline 2. & $\begin{array}{l}\text { Provision of financial assistance by relatives has relevance } \\
\text { in starting and managing a business venture. }\end{array}$ & 162 & 3.22 & 0.67 & Accepted \\
\hline 3. & $\begin{array}{l}\text { Provision of loan facilities by financial institutions has } \\
\text { relevance in starting and managing business venture. }\end{array}$ & 162 & 3.36 & 0.66 & Accepted \\
\hline 4. & $\begin{array}{l}\text { Financial assistance from mentors and peers/colleagues has } \\
\text { relevance in starting up a business venture. }\end{array}$ & 162 & 3.10 & 0.76 & Accepted \\
\hline 5. & $\begin{array}{l}\text { Finance accruing from personal savings has relevance in } \\
\text { starting up a business venture. }\end{array}$ & 162 & 4.02 & 0.78 & Accepted \\
\hline & Aggregate & & $\mathbf{3 . 4 3}$ & $\mathbf{0 . 7 2}$ & Accepted \\
\hline
\end{tabular}

Source: Author's field work

The table above shows that all the mean scores are above 2.50 which is the mean score for decision making. The highest mean score of 4.02 was recorded in item 5 while the lowest mean score was recorded in item 4. The aggregate mean and standard deviation are 3.43 and 0.72 respectively. Since the aggregate mean score is 3.43 and it is above the mean value of 2.50, all the items are therefore accepted which means that financial support has relevance in entrepreneurship.

Research Question Two: To what extent does culture has relevance in starting up an entrepreneurial venture?

Table 2: Examination of the Relevance of Cultural factors in Entrepreneurship

\begin{tabular}{|c|c|c|c|c|c|}
\hline $\mathbf{S} / \mathbf{N}$ & Cultural Factors & $\mathbf{N}$ & Mean & SD & Decision \\
\hline 6. & The value system in a place has relevance in starting up a business venture. & 162 & 3.24 & 0.90 & Accepted \\
\hline 7. & $\begin{array}{l}\text { The pattern of living has relevance in starting up an entrepreneurial } \\
\text { venture. }\end{array}$ & 162 & 3.15 & 0.81 & Accepted \\
\hline 8. & $\begin{array}{l}\text { The belief of the people has relevance in setting up an entrepreneurial } \\
\text { venture. }\end{array}$ & 162 & 2.98 & 0.87 & Accepted \\
\hline \multirow[t]{2}{*}{9.} & Societal stability has relevance in setting up a business venture. & 162 & 3.44 & 0.77 & Accepted \\
\hline & Aggregate & & 3.20 & 0.84 & Accepted \\
\hline
\end{tabular}


Source: Author's field work

The table above shows that all the mean scores are above 2.50 which is the mean score for decision making. The highest mean score of 3.44 was recorded in item 9 while the lowest mean score was recorded in item 8. The aggregate mean and standard deviation are 3.20 and 0.84 respectively. Since the aggregate mean score is 3.20 and it is above the mean value of 2.50 , all the items are therefore accepted which means that cultural factors has relevance in entrepreneurship.

Research Question Three: To what extent does family support has relevance in starting up an entrepreneurial venture?

Table 3: Examination of the Relevance of Family Support in Entrepreneurship

\begin{tabular}{|c|c|c|c|c|c|}
\hline $\mathbf{S} / \mathbf{N}$ & Family Support & $\mathbf{N}$ & Mean & SD & Decision \\
\hline 10. & $\begin{array}{l}\text { Support from parent/guardian has relevance in starting and managing a } \\
\text { business venture. }\end{array}$ & 162 & 3.31 & 0.67 & Accepted \\
\hline 11. & $\begin{array}{l}\text { Support from spouse/partner has relevance in ensuring entrepreneurial } \\
\text { success. }\end{array}$ & 162 & 3.23 & 0.69 & Accepted \\
\hline 12. & $\begin{array}{l}\text { Encouragements from siblings/relatives have relevance in starting and } \\
\text { managing entrepreneurial venture. }\end{array}$ & 162 & 3.41 & 0.85 & Accepted \\
\hline \multirow[t]{2}{*}{13.} & $\begin{array}{l}\text { Co-operation from family members have relevance in ensuring smooth } \\
\text { launching and management of entrepreneurial venture. }\end{array}$ & 162 & 2.91 & 0.88 & Accepted \\
\hline & Aggregate & & 3.22 & 0.77 & Accepted \\
\hline
\end{tabular}

Source: Author's field work

The table above shows that all the mean scores are above 2.50 which is the mean score for decision making. The highest mean score of 3.41 was recorded in item 17 while the lowest mean score was recorded in item 18. The aggregate mean and standard deviation are 3.22 and 0.77 respectively. Since the aggregate mean score is 3.22 and it is above the mean value of 2.50 , all the items are therefore accepted which means that family support has relevance in entrepreneurship.

Research Question Four: To what extent does Entrepreneurship education has relevance in starting up an entrepreneurial venture?

Table 4: Examination of the Impact of Skills and Entrepreneurship Education on Economic Development

\begin{tabular}{|l|l|l|l|l|}
\hline S/N & $\begin{array}{l}\text { Impact of skill and Entrepreneurship Education on Economic } \\
\text { Development }\end{array}$ & Mean & SD & Decision \\
\hline 14. & $\begin{array}{l}\text { Proper skill acquisition and Entrepreneurship Education programmes can } \\
\text { reduce the level of poverty in the country }\end{array}$ & 162 & 3.42 & 0.81 \\
\hline 15. & $\begin{array}{l}\text { A well implemented Entrepreneurship Education programmes can create } \\
\text { more jobs in the country. }\end{array}$ & 162 & 3.49 & 0.76 \\
\hline 16. & $\begin{array}{l}\text { A functional skill acquisition and Entrepreneurship Education programme } \\
\text { can reduce the unemployment rate in the country. }\end{array}$ & 162 & 3.28 & 0.77 \\
\hline 17. & $\begin{array}{l}\text { A well implemented Entrepreneurship Education programme can reduce } \\
\text { the level of insecurity/restiveness resulting from unemployment. }\end{array}$ & 162 & 3.20 & 0.73 \\
\hline 18. & $\begin{array}{l}\text { A functional skill acquisition and Entrepreneurship Education programme } \\
\text { can accelerate the country's Gross Domestic Product (GDP). }\end{array}$ & 162 & 3.43 & 0.67 \\
\hline 19. & $\begin{array}{l}\text { A well implemented Entrepreneurship Education and skill acquisition } \\
\text { programme can reduce the country's dependency on other countries in } \\
\text { terms of goods and services. }\end{array}$ & 162 & 3.38 & 0.69 \\
\hline 20. & $\begin{array}{l}\text { A well implemented Entrepreneurship Education can boost the per capita } \\
\text { income of the country. }\end{array}$ & 162 & 3.40 & 0.68 \\
\hline 21. & $\begin{array}{l}\text { A well implemented skill acquisition and Entrepreneurship Education } \\
\text { programme can raise the standard of living in the country. }\end{array}$ & 162 & 3.44 & 0.77 \\
\hline & Aggregate & Accepted & $\mathbf{3 . 3 8}$ & $\mathbf{0 . 7 4}$ \\
\hline
\end{tabular}

Source: Author's field work

The table above shows that all the mean scores are above 2.50 which is the mean score for decision making. The highest mean score of 3.49 was recorded in item 20 while the lowest mean score was recorded in item 22. The aggregate mean and standard deviation are 3.38 and 0.74 respectively. Since the aggregate mean score is 3.38 and it is above the mean value of 2.50 , all the items are therefore accepted which means that skills and entrepreneurship education has relevance in Economic development.

Table 5: Summary of the Various Sections

\begin{tabular}{|l|l|l|l|l|l|}
\hline S/N & \multicolumn{1}{|c|}{ Sections } & N & Mean & SD & Decision \\
\hline 1. & Financial Support & 162 & 3.43 & 0.72 & Accepted \\
\hline 2. & Cultural Factors & 162 & 3.20 & 0.84 & Accepted \\
\hline 4. & Family Support & 162 & 3.22 & 0.77 & Accepted \\
\hline 5. & $\begin{array}{l}\text { Impact of Skills and Entrepreneurship education on Economic } \\
\text { Development }\end{array}$ & 162 & 3.38 & 0.74 & Accepted \\
\hline & \multicolumn{1}{|c|}{ Aggregate } & & $\mathbf{3 . 3 1}$ & $\mathbf{0 . 7 7}$ & Accepted \\
\hline
\end{tabular}

Source: Author's field work 
The table above shows that all the mean scores are above 2.50 which is the mean score for decision making. The highest mean score of 3.43 was recorded in the first section (financial support) while the lowest mean score of 3.20 was recorded in the second section (cultural factors). Since all the mean value are above 2.50 and the aggregate mean score is 3.32 with a corresponding standard deviation value of 0.76 , all the items are therefore accepted which means that financial support, cultural factors, family support and skills and entrepreneurship education have relevance in Entrepreneurship education.

\section{Discussion of Findings}

The analysis of the research questions raised in the study have revealed some interesting findings that are worth considering and discussing based on some relevant literature to either corroborate or contradict the findings. They are discussed sequentially and systematically in the following paragraphs.

The analysis of research question one reveals that financial support provided to entrepreneurs has relevance in starting up business enterprise. That is, financial support has relevance in entrepreneurship. The finding stressed that provision of financial assistance by relatives has relevance in starting and managing a business venture. Provision of loan facilities by financial institutions also has relevance in starting and managing a business venture. The findings also emphasized that financial assistance from mentors, peers/colleagues and personal savings have relevance in starting up a business venture. The findings of this study is also in support of Shapero and Sokol (1982) where the authors in their model tagged 'Entrepreneurial Event Model (EEM)' emphasized the immense roles that mentors, colleagues and relatives play in ensuring entrepreneurial success. The authors also stressed that the relevance of financial support in ensuring entrepreneurial success and this is the hallmark of entrepreneurship education. Inegbenebor (2006) also emphasized the relevance of mentors and relatives in ensuring entrepreneurial success in his push and pull hypothesis of motivation for starting a business enterprise.

The analysis of research question two reveals that cultural factors have relevance in entrepreneurship. The finding further stressed that the value system in a place and the pattern of living has relevance in starting up an entrepreneurship. The finding further stressed that the value system in a place and the pattern of living has relevance in starting up an entrepreneurial venture. It is also obvious from the finding $\mathrm{s}$ that belief of the people and societal stability have relevance in entrepreneurship. Shapero and Sokol (1982) are also in support of this finding where they stressed that perceptions of desirability (culture) is relevant in ensuring entrepreneurial success.

The analysis of research question three reveals that family support has relevance in ensuring entrepreneurial success. It further shows that support from parent/guardian; spouse/partner and siblings/relatives have relevance in ensuring entrepreneurial success. It is obvious also from the findings that co-operation from family members have relevance in ensuring smooth launching and management of entrepreneurial venture. This finding is in support of the works of Shapero and Sokol (1982) in their Entrepreneurial Event Model where they stressed under 'perceptions of desirability' that the family is an indispensable unit that is relevant in ensuring entrepreneurial success and that for an individual to actually secede in entrepreneurship (business) there must be some level of co-operation between or among the members of the family. Inegbenebor (2006) is also in support of this finding because it has a strong tie with his push and pull hypothesis of motivation for starting a business enterprise.

The analysis of research question four reveals that skills and entrepreneurship education has impact on economic development. The findings reveal great positive impact that a well-implemented and functional entrepreneurship education can produce. The findings show that proper skill acquisition and entrepreneurship education programmes can reduce the level of poverty in the economy. This is in support of Ewubare (2011), Akpomi (2009), Kalirajan (2009) and Ewhrudjakpor (2008). The authors stressed that entrepreneurship education can help in addressing the level of poverty in the country by actively engaging and empowering the graduates of our educational system. In support of this finding, Uloko and Ejinkonye (2010) remarked that when youths are empowered through the acquisition of entrepreneurial skills, there is the possibility that they will use the skills to create new avenues for wealth. The finding also shows that Entrepreneurship education has impact in creating more jobs thereby reducing the level of unemployment in the country. This finding is in support of Akpomi (2009), Adejimola and Olufunmilayo (2009) and Poikkijoki and Heinonen (2006). Akpomi (2006) in support of this finding stressed that the essence of entrepreneurship education is to build in the students entrepreneurship spirit and culture in order to bridge the gap between youth unemployment and job creation. This finding also support Mbionwu (2008) where the author stressed that when youths are given adequate training in skills, they can be self-employed after schooling, hence they become active partners in both community and national development. Another finding worth is that a well implemented entrepreneurship/restiveness resulting from unemployment. This finding is in line with Babalola (2010) where the author stressed that the insecurity is a fall out of poor skill acquisition and entrepreneurship education programme. 


\section{Conclusion}

This paper has indeed empirically investigated the relevance of socio-cultural factors in entrepreneurial venture and some of the findings in this paper corroborate previous findings by other researchers in the field. Based on the literatures reviewed and the new findings that came up from the research work, the paper therefore concludes that financial, family and cultural factors has relevance in ensuring the success of entrepreneurial venture and that Entrepreneurship education and skills are capable of promoting economic development which will be translated in the lives of the citizens.

\section{Recommendations}

This empirical investigation has revealed outstanding findings and based on that, the following recommendations are therefore advanced:

i. Government should provide accessible and affordable loan facilities for graduates of the programme;

ii. Financial institutions should provide suitable loan scheme to interested graduates of the programme;

iii. Individuals should learn to cultivate the habit of saving irrespective of what they are earning;

iv. Entrepreneurs should take time to carry out a feasibility study and examine the culture of the people before embarking on any line of business;

v. Entrepreneurs/would-be entrepreneurs should maintain cordial relationship with their family members and not work in isolation.

vi. All bodies and stakeholders should ensure that there is proper implementation of entrepreneurship education in order to achieve its goals;

vii. There should be proper mentoring relationship between successful entrepreneurs and would-be entrepreneurs so as to get necessary assistance from the mentor; and

\section{Reference}

[1]. Adejimola, A.S. \& Olufunmilayo, T. (2009). Spinning off an Entrepreneurship Culture among Nigerian University Students; Prospects and Challenges. African Journal of Business Management, 3(1), 80-88.

[2]. Akpomi, M.E. (2009). Achieving Millennium Development Goals (MDGs) through Teaching Entrepreneurship Education in Nigeria Higher Education Institutions (HEIs). Eur. J. Soc. Sci. 8 (1), 154-157.

[3]. Akudolu, L.R. (2010). A Curriculum framework for Entrepreneurship Education in Nigeria. Unizik Orient Journal of Education, 5 (2), 1-16.

[4]. Babalola, J.B. (2010). Eyeing Sustainable Development. Entrepreneurship: Entrepreneurship Climate must Change in Nigeria, Ibadan: Lineage Publishing House.

[5]. Ediagbonya, K. (2013). The Roles of Entrepreneurship Education in Ensuring Economic Empowerment and Development. Journal of Business Administration and Education, 4(1), 35-46.

[6]. Ewhrudjakpor, C. (2008). Poverty and its Alleviation: The Nigerian Experience. Journal of International Social Work, 51(4), 519531.

[7]. Ewubare, M.U. (2010). Strategies for Promoting Entrepreneurship Education in (NCE) Home Economics. JHER, 13, 137-143.

[8]. Federal Republic of Nigeria. (2004). National Policy on Education. Lagos: NERDC Press.

[9]. Hornby, A.S. (2001). Oxford Advanced Learner's Dictionary $\left(6^{\text {th }}\right.$ Ed.). New York: Oxford University Press.

[10]. Imeokparia, P.O. \& Ediagbonya, K. (2010). Empirical Analysis of Secondary Schools' Perception about a Good Teacher in Egor Local Government Area, Edo State. Journal of Curriculum Studies and Instruction, 4, 36-49.

[11]. Imeokparia, P.O. \& Ediagbonya, K. (2013). Quality Assurance in Entrepreneurial Studies in College of Education, Ekiadolor, Benin City. European Journal of Educational Studies, $5 \quad$ (2), 293-301.

[12]. Inegbenebor, A.U. (2006). You Can Be an Entrepreneur. In A.U. Inegbenebor (Ed). The Fundamentals of Entrepreneurship (pp,1-14), Benin: Mindex Press Limited.

[13]. Kalirajan, K. (2009). The Pace of Poverty Reduction Across the Globe: An Exploratory Analysis. International Journal of Social Economics, 36(6), 692-705.

[14]. Mbionwu, U. (2008). School Administration in a Dwindling Economy: Nigeria Case. Awka: Erudite printers.

[15]. Omorogiuwa, K.O. (2006). Applied Research and Statistics in Education. Benin: Mindex Publishing Company.

[16]. Poikkijoki, S. \& Heinonen, J. (2006). An Entrepreneurial-Directed Approach to Entrepreneurship Education: Mission Impossible. Journal of Management Development, 25(1), 80-94.

[17]. Shapero, A., \& Sokol, L. (1982). The Social Dimensions of Entrepreneurship. In C. Kent, Sexton, ～D., Vesper, K. (Ed.), Encyclopedia of Entrepreneurship: 72-90. Englewood Cliffs, New Jersey: Prentice-Hall, Inc.

[18]. Uloka, M. E., \& Ejinkonye, U. B. (2010). Entrepreneurial education and training for job creation. A paper presented at main Hall College of Education, Ekiadolor-Benin, Edo State, 12th - $\quad$ 6th, July.

[19]. Urbano, D, Aponte, M \& Toledano, N. (2008). Doctoral Education in entrepreneurship: European Case Study. Journal of Small Business and Enterprise Development, 15(2), 336-347. 